\title{
The orchid bee fauna (Hymenoptera, Apidae) of a core area of the Cerrado, Brazil: the role of riparian forests as corridors for forest-associated bees
}

\author{
Luiz Roberto Ribeiro Faria ${ }^{1,2,3}$ \& Fernando Amaral da Silveira ${ }^{1}$ \\ ${ }^{1}$ Programa Pós-graduação em Ecologia, Conservação e Manejo de Vida Silvestre, \\ Departamento de Zoologia, Universidade Federal de Minas Gerais - UFMG, \\ CP 486, CEP 30123-970, Belo Horizonte, MG, Brazil \\ ${ }^{2}$ Departamento de Ciências Agrárias e Biológicas, Centro Universitário Norte do Espírito Santo - CEUNES, \\ Universidade Federal do Espírito Santo - UFES, \\ Rod. BR 101 Norte, Km 60, Litorâneo, CEP 29932-540, São Mateus, ES, Brazil \\ ${ }^{3}$ Corresponding author: Luiz Roberto Ribeiro Faria, e-mail: nunofariajr@gmail.com
}

FARIA, L.R.R. \& SILVEIRA, F.A. The orchid bee fauna (Hymenoptera, Apidae) of a core area of the Cerrado, Brazil: the role of riparian forests as corridors for forest-associated bees. Biota Neotrop. 11(4): http://www. biotaneotropica.org.br/v11n4/en/abstract?article+bn02111042011

\begin{abstract}
The composition of local orchid-bee faunas (Hymenoptera, Apidae, Euglossina) in open-vegetation domains is poorly known, making the ecology and biogeography of the group difficult to understand. The aim of this work was to answer the following questions: i) Is the orchid-bee fauna composition, species richness and abundance in the cerrado (Brazilian savanna) sensu stricto similar to that of riparian forests immersed in that domain? ii) Do species from neighboring forest domains use riparian forests as mesic corridors into the Cerrado? Two sites in cerrado s.s. and two in riparian forests were sampled monthly, one day per month, during one year (Nov/2003-Oct/2004) in northwestern Minas Gerais state, Brazil. Six aromatic compounds ( $\beta$-ionone, 1,8-cineole, eugenol, methyl trans-cinnamate, methyl salicilate and vanillin) were exposed from 8:00 AM to 4:00 PM to attract orchid bees. The results suggest that: i) The composition of the orchid bee fauna in the two kinds of environments is the same; ii) Riparian forests apparently have no role as mesic corridors for penetration of forest-dependent euglossine species into the core of the Cerrado Domain.
\end{abstract}

Keywords: Euglossina, riparian forest, gallery forest, savanna, landscape ecology.

FARIA, L.R.R. \& SILVEIRA, F.A. A fauna de abelhas euglossinas (Hymenoptera, Apidae) em uma área central do Cerrado, Brasil: importância das florestas ripárias como corredores para espécies de abelhas associadas a florestas. Biota Neotrop. 11(4): http://www.biotaneotropica.org.br/v11n4/pt/abstract?article+bn02111042011

Resumo: A composição das faunas locais de Euglossina (Hymenoptera, Apidae) em formações vegetais abertas é pouco conhecida, o que dificulta o entendimento da ecologia e biogeografia do grupo. O objetivo deste trabalho foi responder às seguintes perguntas: i) No domínio do Cerrado, a composição da fauna, riqueza em espécies e abundância de euglossinas em áreas de cerrado s.s. e em mata ciliar são semelhantes entre si? ii) Espécies de domínios florestais adjacentes utilizam as matas ciliares como corredores mésicos para dentro do Cerrado? Duas áreas de cerrado s.s. e duas de mata ciliar foram amostradas mensalmente, um dia por mês, durante um ano (nov/2003-out/2004), no noroeste do estado de Minas Gerais, Brasil. Seis compostos aromáticos ( $\beta$-ionona, cineol, cinamato de metila, eugenol, salicilato de metila e vanilina) eram expostos das 8 às 16 horas para atrair as euglossinas. Os resultados encontrados sugerem que: i) As composições das faunas em áreas de cerrado s.s. e matas ciliares são iguais; ii) As matas ciliares aparentemente não atuam como corredores mésicos para a penetração, em áreas centrais do Cerrado, de espécies de euglossinas dependentes de florestas.

Palavras-chave: Euglossina, mata ciliar, mata de galeria, savana, ecologia de paisagem. 


\section{Introduction}

The discovery of aromatic compounds attractive to euglossine bees (Dodson et al. 1969) made it possible for the development of standardized collecting methods, which caused a boom on faunistic studies on this bee group. Despite this, most of the inventories of their fauna were performed in tropical forests, with only a couple of studies done in savannic environments (Nemésio \& Faria 2004, Alvarenga et al. 2007).

Despite the fact that the Cerrado occupies around $23 \%$ of the Brazilian territory (Ratter et al. 1997) and is one of the World biodiversity hotspots (Myers et al. 2000), its bee fauna is still poorly known (Silveira \& Campos 1995, Albuquerque \& Mendonça 1996, Carvalho \& Bêgo 1998, Andena et al. 2005). This is especially true for orchid bees, since they were poorly inventoried in this ecological domain and always in marginal areas (Aguilar 1990, in the state of Bahia; Rebêlo \& Cabral 1997, Carvalho et al. 2006 and Mendes et al. 2008, in the state of Maranhão; and Nemésio \& Faria 2004, Alvarenga et al. 2007 and Freitas 2009 in the state of Minas Gerais). Thus, studies in the core area of the Cerrado are much needed, especially considering i) the level of antropogenic pressure it currently sustains, and ii) its central position in South America relative to other ecosystems, as the Amazonian and Atlantic tropical forests, and the semiarid Chaco and Caatinga domains (Pinheiro \& Ortiz 1992, Silva 1997, Myers et al. 2000).

The Cerrado is a mosaic of vegetational physiognomies, varying from open fields to dry forests. Riparian forests (both ciliary and gallery forests), running across this mosaic were said to be important mesic corridors that allow for the colonization of the Cerrado by forest-dependent mammalians (Redford \& Fonseca 1986, Mares \& Ernst 1995, Lacher Junior \& Alho 1998), birds (e.g. Silva 1996), butterflies (Pinheiro \& Ortiz 1992) and wasps (Diniz \& Kitayama 1998). The importance of these mesic corridors to euglossine bees in open environments was suggested by Neves \& Viana (1999), Carvalho et al. (2006), Nemésio et al. (2007), Anjos-Silva (2008) and Moura \& Schlindwein (2009).

Studies on the diversity, distributional patterns and faunistic composition of the Cerrado are urgently needed, since large areas in this domain are being transformed into crops, pastures (Camargo \& Becker 1999, Castro et al. 2008, Carrijo et al. 2009) and forests of exotic trees, mainly eucalypts (Oliveira 1998). Evidences suggest that habitat alteration may affect local faunas of pollinating insects (e. g. Aizen \& Feinsinger 1994, Steffan-Dewenter et al. 2002) and that these effects can be more pronounced in tropical areas (Ricketts et al. 2008). Evidence of impacts of habitat disturbance on euglossine bees has been found by Nemésio \& Silveira (2007a, 2010) and Brosi (2009).

This study intended to inventory one local euglossine-bee fauna and to answer the following questions: i) Are the euglossine species composition, species richness, and abundance in areas of cerrado sensu stricto similar to those in nearby riparian forests? ii) Do forestdependent euglossine species from the Amazonian and Atlantic Forest domains use the riparian forests as mesic refuges in the Cerrado?

\section{Material and Methods}

Sampling was done in the "Fazenda Brejão" (V\&M Florestal Ltda - from here on "Brejão"). This is a 36,000 ha farm located in the municipality of Brasilândia de Minas, northwestern Minas Gerais state. Different physiognomies of the Cerrado are present in Brejão 15,899 ha are covered by cerrado s.s.; 4,435 ha by "campo cerrado"; 1,750 ha by "veredas" and 1,295 ha by riparian forests (for an account on these physiognomies, see Goodland 1971 and Ribeiro \& Walter 1998). Other 12,510 ha are planted with a few different species of Eucalyptus spp. (Scolforo et al. 2001). The regional climate is drysubhumid tropical of Holdridge, with annual average temperatures between 22 and $24{ }^{\circ} \mathrm{C}$ and average rainfall between 700 and $1,200 \mathrm{~mm}$, with most of the rain occurring in January and February (Golfari 1975). In referring to the vegetational domain sampled and its several physiognomies, the term "Cerrado" (in capital) is used for the whole domain, while "cerrado" refers to the cerrado sensu stricto physiognomy, which is formed by an open-canopy collection of short, contorted trees, with an understory composed of grasses and bushes (see Goodland 1971 and Ribeiro \& Walter 1998).

Four sampling sites were defined at Brejão, two in the cerrado sensu stricto and two in the riparian forest bordering the Paracatu river (physiognomies sensu Goodland 1971 and Ribeiro \& Walter 1998). Logistic limitations precluded more replicates to be done in each environment. Coordinates and elevations for these sites are as follows: i) "Cerrado 1" (C1) - $17^{\circ} 02$ ' $22^{\prime \prime} \mathrm{S}$ and $45^{\circ} 51^{\prime} 03$ " W,

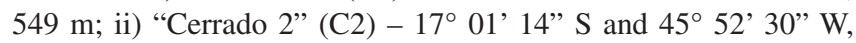
$565 \mathrm{~m}$; iii) "Riparian forest 1 " (F1): $17^{\circ} 04^{\prime} 27^{\prime}$ ' $\mathrm{S}$ and $45^{\circ} 54^{\prime} 15^{\prime \prime} \mathrm{W}$, $493 \mathrm{~m}$; iv) "Riparian forest 2" (F2): $17^{\circ} 05^{\prime} 29^{\prime}$ " $\mathrm{S}$ and $45^{\circ} 57^{\prime} 15^{\prime \prime} \mathrm{W}$, $491 \mathrm{~m}$ (Figure 1). The straight-line distances between these sites are presented in Table 1.

Six aromatic compounds were employed to attract Euglossina: $\beta$-ionone, cineole, eugenol, methyl trans-cinnamate, methyl salicylate and vanillin. These compounds were presented to bees monthly, from November 2003 to October 2004, between 8:00 AM and 4:00 PM, one day in each sampling site. In most cases, two collectors sampled the two sites of the same environment simultaneously. Site F2 could not be sampled in February 2004, when it was flooded. In March 2004, all sites were sampled only between 9:00 AM and 3:00 PM.

The aromatic compounds were imbibed in cotton swabs and hang about $1.5 \mathrm{~m}$ above ground level, $2 \mathrm{~m}$ apart from each other. Baits were disposed in such a way that the collector could observe all of them simultaneously. Bees attracted were caught with hand nets, killed in ethyl acetate and pinned for identification. They are deposited in the entomological collection of the Coleções Taxonômicas da Universidade Federal de Minas Gerais, Belo Horizonte. Specimen identification was done with the help of keys (Bonilla-Gómez \& Nates-Parra 1992 and Rebêlo \& Moure 1996) and by comparison with specimens previously identified by specialists. Nomenclature of species is presented in two ways in Table 2: following Moure et al. (2007) and according to Nemésio's (2009) proposal. Throughout the text, the classification follows the treatment of Moure et al. (2007).

The diversity indexes of Shannon-Wiener (H') and Simpson (1-D) were calculated according to Ludwig \& Reynolds (1988) and Magurran (1988). Shanon-Wiener values for the several sampling sites were compared using the Hutcheson t-test (Zar 1996). Similarity among sites was calculated based on species frequencies, using the Renkonen similarity index, according to the recommendation by Wolda (1981) for small samples, and the areas grouped using UPGMA (Sneath \& Sokal 1973). A principal component analysis was undertaken, using square root-transformed data of species frequency (Manly 1994, Zar 1996).

\section{Results}

Only 113 specimens of eight euglossine species were captured after a total of 368 sampling hours in the four sampling sites together (Table 2). The most abundant species, considering all four sites, were

Table 1. Straight-line distances $(\mathrm{km})$ between the sampling sites in the Fazenda Brejão.

\begin{tabular}{lcccc}
\hline & Cerrado 1 & Cerrado 2 & Forest 1 & Forest 2 \\
\cline { 1 - 4 } Cerrado 1 & - & 4.3 & 5.3 & 10.5 \\
Cerrado 2 & 4.3 & - & 7.8 & 12.9 \\
Forest 1 & 5.3 & 7.8 & - & 6.5 \\
Forest 2 & 10.5 & 12.9 & 6.5 & - \\
\hline
\end{tabular}




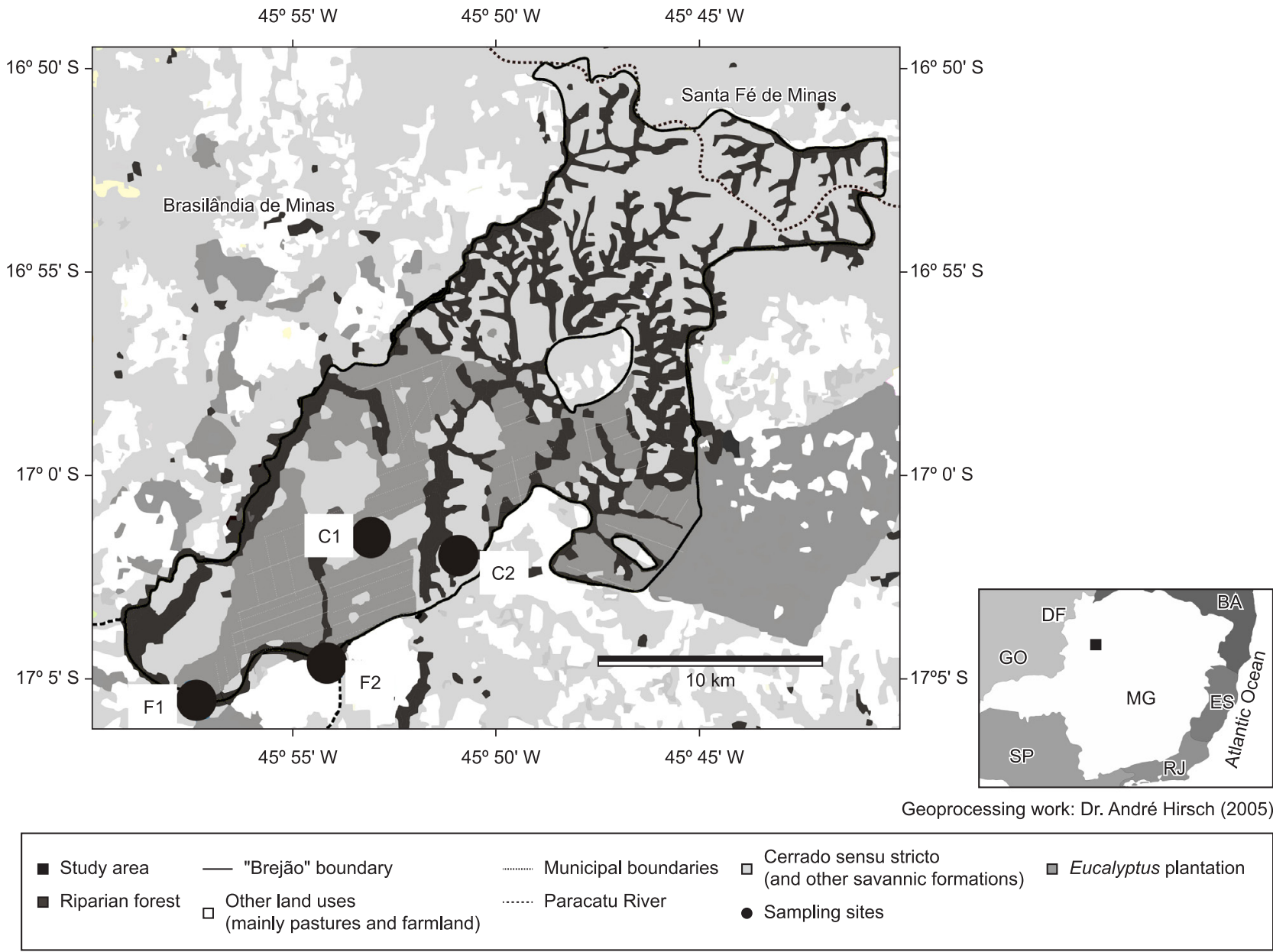

Figure 1. Location of sampling sites and classes of land cover in the "Fazenda Brejão", Brasilândia de Minas, Brazil.

Table 2. Male euglossine abundance, species richness and diversity at Fazenda Brejão, according to sampling sites and aromatic baits $(b$ : $\beta$-ionone; $c l$ : cineole; ct: methyl trans-cinnamate; $e$ : eugenol; $s$ : methyl salicilate; $v$ : vanillin.

\begin{tabular}{|c|c|c|c|c|c|c|c|c|c|c|c|c|c|c|c|c|c|c|c|c|c|c|c|c|c|}
\hline \multirow[t]{2}{*}{ Species } & \multicolumn{6}{|c|}{ Cerrado 1} & \multicolumn{6}{|c|}{ Cerrado 2} & \multicolumn{6}{|c|}{ Forest 1} & \multicolumn{6}{|c|}{ Forest 2} & \multirow[t]{2}{*}{ Totals } \\
\hline & $b$ & cl & $c t$ & $e$ & $s$ & $v$ & $b$ & $c l$ & $C t$ & $e$ & $s$ & $v$ & b & cl & $c t$ & $e$ & $s$ & $v$ & b & $c l$ & $\overrightarrow{c t}$ & $e$ & $S$ & $v$ & \\
\hline Euglossa townsendi ${ }^{l}$ Cockerell, 1904 & 0 & 9 & 0 & 0 & 0 & 0 & 0 & 0 & 0 & 0 & 0 & 0 & 0 & 0 & 0 & 0 & 0 & 0 & 0 & 0 & 0 & 0 & 0 & 0 & 9 \\
\hline Euglossa cordata ${ }^{2}$ (Linnaeus, 1758$)$ & 0 & 2 & 0 & 0 & 0 & 0 & 1 & 1 & 0 & 0 & 0 & 0 & 1 & 0 & 0 & 0 & 0 & 0 & 2 & 2 & 0 & 0 & 0 & 1 & 10 \\
\hline Euglossa violaceifrons ${ }^{3}$ Rebêlo \& Moure, 1996 & 0 & 0 & 0 & 0 & 0 & 0 & 0 & 0 & 0 & 0 & 0 & 0 & 0 & 0 & 0 & 0 & 0 & 0 & 0 & 1 & 0 & 0 & 0 & 0 & 1 \\
\hline Euglossa fimbriata Rebêlo \& Moure, 1996 & 0 & 6 & 0 & 0 & 0 & 0 & 0 & 0 & 0 & 0 & 0 & 0 & 0 & 0 & 0 & 0 & 0 & 0 & 0 & 0 & 0 & 0 & 0 & 0 & 6 \\
\hline Euglossa melanotricha Moure, 1967 & 0 & 8 & 0 & 2 & 0 & 0 & 0 & 5 & 0 & 1 & 0 & 0 & 0 & 2 & 0 & 0 & 0 & 0 & 0 & 1 & 0 & 0 & 0 & 0 & 19 \\
\hline Euglossa securigera Dressler, 1982 & 0 & 16 & 2 & 4 & 0 & 0 & 0 & 3 & 0 & 0 & 0 & 0 & 0 & 2 & 1 & 4 & 0 & 0 & 0 & 0 & 0 & 0 & 0 & 0 & 32 \\
\hline Euglossa sp. & 0 & 1 & 0 & 0 & 0 & 0 & 0 & 0 & 0 & 0 & 0 & 0 & 0 & 0 & 0 & 0 & 0 & 0 & 0 & 0 & 0 & 0 & 0 & 0 & 1 \\
\hline Eulaema nigrita Lepeletier, 1841 & 0 & 19 & 0 & 0 & 0 & 0 & 0 & 2 & 0 & 0 & 0 & 0 & 0 & 5 & 0 & 0 & 0 & 1 & 0 & 8 & 0 & 0 & 0 & 0 & 35 \\
\hline Total of specimens & \multicolumn{6}{|c|}{69} & \multicolumn{6}{|c|}{13} & \multicolumn{6}{|c|}{16} & \multicolumn{5}{|c|}{15} & \multicolumn{2}{|r|}{113} \\
\hline Number of species & \multicolumn{6}{|c|}{ 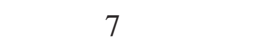 } & \multicolumn{6}{|c|}{4} & \multicolumn{6}{|c|}{4} & \multicolumn{6}{|c|}{4} & 8 \\
\hline Diversity (Simpson) & \multicolumn{6}{|c|}{0.775} & \multicolumn{6}{|c|}{0.686} & \multicolumn{6}{|c|}{0.648} & \multicolumn{6}{|c|}{0.595} & 0.778 \\
\hline Diversity (Shannon-Wiener) & \multicolumn{6}{|c|}{1.642} & \multicolumn{6}{|c|}{1.271} & \multicolumn{6}{|c|}{1.163} & \multicolumn{6}{|c|}{1.063} & 1.676 \\
\hline
\end{tabular}

Recently, Nemésio (2009) proposed the following new names or synonymies for these species: ${ }^{1}$ Euglossa aratingae Nemésio, 2009; ${ }^{2}$ Euglossa carolina Nemésio, 2009; and ${ }^{3}$ Euglossa despecta Moure, 1968.

Eulaema nigrita Lepeletier, 1841, Euglossa securigera Dressler, 1982 and Euglossa melanotricha Moure, 1967. Of the species collected, seven were recorded in the cerrado sites (all of them in $\mathrm{C} 1$ and four in C2) and five in the forest sites (four in each site). Three species, Euglossa fimbriata Rebêlo \& Moure, 1996, Euglossa townsendi Cockerell, 1904 and Euglossa sp. (a singleton) were found only in the cerrado s.s. sites, while Euglossa violaceifrons Rebêlo \& Moure, 1996 (a singleton) was collected only in the riparian forest. Only three species were present in all four sites: El. nigrita, Eg. cordata and Eg. melanotricha. El. nigrita, despite being the most abundant species when all sites are considered, was the most frequent species only in F2. 
The orchid-bee assemblages in the cerrado stricto sensu were more diverse than those in the riparian forest (Table 2). C1 was the most diverse site of all, and its diversity index was significantly larger than that of $\mathrm{C} 2(\mathrm{t}=5.52 ; d f=22 ; \mathrm{p}<0.01), \mathrm{F} 1(\mathrm{t}=6.85 ; d f=26$; $\mathrm{p}<0.01)$ and $\mathrm{F} 2(\mathrm{t}=6.98 ; d f=21 ; \mathrm{P}<0.01)$. There was also a significant difference between the diversity calculated for $\mathrm{C} 2$ and $\mathrm{F} 2(\mathrm{t}=2.18 ; d f=29 ; \mathrm{p}<0.05)$. There were no statistical differences between the diversities found in $\mathrm{C} 2$ and F1 and in F1 and F2.

The cluster analysis did not group together sites from the same physiognomic type. $\mathrm{C} 1$ and $\mathrm{F} 1$ were the two most similar sites (74.8\%) and their similarity is largely due to the dominance of Eg. securigera and to the similar frequencies of Eg. melanotricha and El. nigrita. The most distinctive site was F2, due to the high frequencies of Eg. cordata and El. nigrita. In the PCA analysis, $74.9 \%$ of the variance was explained by the first component and almost $100 \%$ by the three first ones. Eg. securigera, Eg. townsendi and Eg. fimbriata were the main contributors to the variance in the first component and Eg. melanotricha the main contributor in the second one. Eg. fimbriata and Eg. townsendi, recorded only in $\mathrm{C} 1$, most likely were responsible for placing this site separate from the others.

\section{Discussion}

\section{Species richness and composition}

The species richness in Brejão was similar to those found in other inventories carried out in the Cerrado domain (Aguilar 1990, Rebêlo \& Cabral 1997, Alvarenga et al. 2007, Nemésio \& Faria 2004) and in fragments of the semideciduous "low mountain rain forest" (Rizzini 1979), at elevations of 300-900 m, in the Atlantic Forest domain in the states of Minas Gerais (Nemésio 2003, Nemésio \& Silveira 2007a, 2010), São Paulo (Rebêlo \& Garófalo 1997) and Paraná (Sofia \& Suzuki 2004). These forests are characterized by relatively open canopy, 15-25 m tall, and occur under climates with two well defined seasons, rainy and dry. This suggests that the species richness of local faunas in the Cerrado is comparable to those in the so called "inland forests" within the Atlantic Forest Domain. Similar species richness was found also by Neves \& Viana (1999) in other inventory of a euglossine fauna of a riparian forest. In this case, however, the forest was within a semiarid matrix of Caatinga vegetation. Such species richnesses, however, are much smaller than those found in coastal Atlantic Forest sites in southeastern Brazil (Bonilla-Gómez 1999, Tonhasca Junior et al. 2002, Nemésio \& Silveira 2006a) and in the Amazonian Forest (e. g. Oliveira \& Campos 1995, StorckTonon et al. 2009). The low abundance of orchid bees found in Brejão and in the other sites sampled in the Cerrado is in accordance with the pattern found for local bee faunas in general in the Cerrado (Silveira \& Campos 1995). These authors suggested that this low abundance might result from relative food scarcity, which, in turn, would be a consequence of a combination of low soil fertility and relatively low seasonal precipitation (for the characteristics of the Cerrado soil, see Queiroz-Neto 1982). However, it is important to highlight that this pattern is not a general pattern for all the groups of bees in the Cerrado, since some groups (e.g. Centridini and Exomalopsini) seems to be more diverse in savanna-like formations than in rainforests (see e.g. Pinheiro-Machado et al. 2002).

Most of the previous inventories of orchid bees in the Cerrado were carried out at the borders of this domain (e. g. Rebêlo \& Cabral 1997, Alvarenga et al. 2007, Nemésio \& Faria 2004) and the presence of some euglossine species in these surveys (e. g. Euglossa imperialis Cockerell, 1922 and Euglossa annectans Dressler, 1982 [Nemésio \& Faria 2004 treated Eg. annectans as Eg. stellfeldi Moure, 1947; see Faria \& Melo 2007 for details and Nemésio 2009 for an alternative treatment of this species]) previously found only in forest habitats, was probably due to the influence of nearby forest environmentsAmazonian forest in the case of Maranhão state (Rebêlo \& Cabral 1997; Carvalho et al. 2006; Mendes et al. 2008) and Atlantic forest in the case of Minas Gerais state (Nemésio \& Faria 2004 and Alvarenga et al. 2007). Moreover, our data, collected in the core area of the Cerrado and far away from both forest domains, suggest that there is not an orchid-bee fauna endemic to the Cerrado. Instead, the euglossine species occurring in this domain seem to bee a subset of the euglossine fauna in the Atlantic Forest, composed of bees species found in the seasonal, low-canopy forests occurring at altitudes above $800 \mathrm{~m}$ along the Espinhaço range and which are in close contact with the Cerrado (see Nemésio \& Faria 2004, Nemésio $\&$ Silveira 2007b). The same species found in the Cerrado of Minas Gerais are also present in the riparian forests within the Caatinga semiarid domain, at the margins of the São Franciso river, in the state of Bahia (Neves \& Viana 1999), with the exceptions of two species of Eufriesea Cockerell (a genus of relatively rare, highly seasonal species) collected in the latter. It should be noted that the São Francisco river crosses the Cerrado of Minas Gerais from south to north, entering the Caatinga domain. Since the Paracatu river is a large tributary of the São Francisco, its riparian forests probably where originally continuous all the way down to its mouth on the latter and, from there, northward into Bahia. The results recently presented by Moura \& Schlindwein (2009) reinforce this hypothesis, since the species of Euglossa collected by them at the medium course of the São Francisco river, in a matrix of caatinga, were also the same collected in Brejão. Moura \& Schlindwein (2009) only collected distinct species, such as Euglossa crassipunctata Moure, 1968 and Euglossa perpulchra Moure \& Schlindwein, 2002, near the mouth of the São Francisco river, where the influence of rain forests may occur.

It is important to notice that the species recorded here are also found in highly disturbed areas such as small forest fragments in urban landscapes (Nemésio \& Silveira 2007a). The two most common species, El. nigrita and Eg. securigera (comprising, together, 60\% of the collected bees), are known for their preference for open and/ or disturbed areas. Eulaema nigrita is considered indicative of open and/or disturbed areas (e. g. Nemésio \& Silveira 2007a, Aguiar \& Gaglianone 2008), being able to nest in pre-existing cavities in disturbed areas, including large cities (Silveira, personal observation). Their males were shown to be able to fly $500 \mathrm{~m}$ out of forest fragments into a sugarcane matrix to get aromatic compounds (Milet-Pinheiro \& Schlindwein 2005) and to cross urban areas (Raw 1989) and pastures (Tonhasca Junior et al. 2003) between forested areas. E. securigera is also able to cross pastures (Tonhasca Junior et al. 2003) and was considered as "common in the forest edge" by Nemésio \& Silveira (2006a) what is supported by data from Tonhasca Junior et al. (2002) and Milet-Pinheiro \& Schlindwein (2005).

These species commonly encountered in the Cerrado may be expanding their geographic range toward areas previously covered by lowland tropical forest, such as the Rio Doce valley, where Eg. cordata and El. nigrita were recorded, mainly in the forest borders (Nemésio \& Silveira 2006a). However, our current knowledge of the biogeographic history and phylogenetic relationships of euglossine bees do not allow us to clearly distinguish if open-forest species at the borders of tropical forest domains such as the Atlantic Forest and the Amazonian Forest invaded the Cerrado or vice-versa. However, the first hypothesis seems to be more reasonable, given that euglossine bees reach their greatest diversity and abundance in rainforest environments (Dressler 1982, Roubik \& Hanson 2004, Nemésio \& Silveira 2007b). Their presence in open vegetation domains, such as the Cerrado, thus, would be the result of secondary colonization by species adapted to the relatively sunny, dry, and windy forest-border habitat. 


\section{Influence of riparian forests}

Contrary to what has been found for other insects, such as frugivorous butterflies (Pinheiro \& Ortiz 1992) and wasps (Diniz \& Kitayama 1998), and for vertebrates such as birds (Silva 1996) and mammals (Redford \& Fonseca 1986), the result of the cluster analysis suggests that, inside the Cerrado domain, there are no orchid-bee species clearly associated to the savannic or to the forest environments. This was also the conclusion reached by Nemésio \& Faria (2004). Reasons for this discrepancy are not so obvious and, of course, one cannot dismiss the possibility of the current species-composition of the euglossine fauna in the riparian forests of the Fazenda Brejão result from mid-term anthropic impact on the local environment. An alternative explanation, however, would be that riparian forests in the Cerrado domain do not offer the kind of humid, shady environments adequate for euglossine bees dependent on rainforests and intolerant to borders (see Morato 1994, Tonhasca Junior et al. 2002, Nemésio \& Silveira 2006a, 2010). Generally, riparian forests are relatively narrow in both river margins, rarely reaching over $100 \mathrm{~m}$ wide (Ribeiro \& Walter 1998). This would make the entire environment inside these forests to be affected by edge effects (see Begon et al. 1990, Murcia 1995). It has been suggested that some species in the Atlantic Forest are strongly associated to forest interiors (e.g. Euglossa analis Westwood, 1840 and Euglossa sapphirina Moure, 1968 - Nemésio \& Silveira 2006a, Tonhasca Junior et al. 2002) and that their distributions are determined by their different tolerance to light, temperature, and humidity (Morato 1994). Nemésio \& Silveira (2006a) suggested that, at $50 \mathrm{~m}$ from the forest border, the euglossine-bee community would still be under strong influence of these factors. Moreover, data by Nemésio \& Silveira (2010) suggest that only forests with large core areas distant at least $100 \mathrm{~m}$ of the borders would sustain viable populations, even of species living in forests with relatively open canopies. If this is true, then, orchid bees intolerant to forest borders would be unable to survive in the riparian forests in the Cerrado domain.

The only species found exclusively in the forest environment in the Fazenda Brejão, Eg. violaceifrons, was represented by a single specimen in our samples. For this reason, its absence in the cerrado $s$. $s$. may be due to chance alone. Moreover, a close association of this species to forest environments is unlikely, since it has been collected in a variety of habitats, including forest margins and disturbed open areas (Bonilla-Gómez 1999, Rebêlo \& Moure 1996, Rebêlo \& Garófalo 1997, Silva \& Rebêlo 1999, 2002, Neves \& Viana 2003, Jesus 2000). Some of the other species collected in the Fazenda Brejão, such as El. nigrita and Eg. cordata, are known to be tolerants to both forest borders and disturbed environments (see Nemésio \& Silveira 2006a, 2007a, Aguiar \& Gaglianone 2008, Milet-Pinheiro \& Schlindwein $2005)$ and, thus, their presence in the two environments here studied is not surprising. The dominance of El. nigrita in the Cerrado of Brasilândia de Minas is in accordance with its apparent association with open areas, as suggested by Morato (1994), Peruquetti et al. (1999), Tonhasca Junior et al. (2002) and Nemésio \& Silveira (2007a). However, Nemésio \& Silveira (2006b) suggested that the abundance of the nest-parasite species of Exaerete could be, also, an important factor determining the abundance of El. nigrita. Thus, in regions as that of the Fazenda Brejão, where species of Exaerete are absent or very rare, females of El. nigrita may attain greater reproductive success.

Interestingly, at the Fazenda Brejão, Euglossa securigera reached remarkably high frequencies, considering its representation in other surveys in the Cerrado and other environments (Nemésio 2009). Nemésio \& Silveira (2006a), sampling the margin and interior of a large Atlantic Forest fragment, observed that this species, similarly to El. nigrita, was significatively more abundant at the forest margin. This also suggests a close relationship between these species and open environments. Similarly, Eg. melanotricha also seems to be associated to open environments, although only at altitudes above $500 \mathrm{~m}$ (Nemésio \& Faria 2004). It is interesting to note, however, that contrary to El. nigrita and Eg. securigera, which are pan-neotropical species, Eg. melanotricha is restricted to the Atlantic Forest and Cerrado domains (see Nemésio \& Silveira 2007b, Nemésio 2009).

It also should be considered that samples from riparian forests in different regions of the Cerrado domain may result in different patterns. Oliveira-Filho \& Ratter (1995), in a floristic analysis of the riparian forests of central Brazil, found two groups of forests, the first one occurring in the central and southern portions of the Cerrado domain (in the Distrito Federal and in the states of Goiás and Minas Gerais) which seem to be strongly associated to the seasonal, semideciduous forests occurring in the southern state of Paraná. The second group, more widespread than the first, occurs in the western and northern regions of the Cerrado (states of Mato Grosso and Tocantins). This last type of forest is intermixed with "cerradões" (the forest phase of the Cerrado) and forests of the southern border of the Amazonian domain. It is possible, thus, that the sampling of riparian forests in this northern portion of the Cerrado reveals the presence of Amazonian euglossine species. The findings of Aglae caerulea Lepetier \& Serville, 1825 and Euglossa cognata Moure, 1970 in southwestern Mato Grosso state by Anjos-Silva et al. (2006) and Anjos-Silva (2008) support this hypothesis. Data from Carvalho et al. (2006) also seems to endorse this hypothesis. These authors found some forest related euglossine species (e.g. Eufriesea ornata (Mócsary, 1896), Euglossa gaianii Dressler, 1982 and Euglossa modestior Dressler, 1982) in a riparian forest in the municipality of Urbano Santos, Maranhão state (see Carvalho et al. 2006). It must be pointed out, however, that the Cerrado in northeastern Maranhão is mainly compound by "Cerradão" (the forest physiognomy of the biome) (Silva et al. 2008) and that these authors also assessed a periferic area of the Cerrado biome. Thus, it seems to be much more reasonable to find some forest-dependent elements in a riparian forest in this region than in a core area of Cerrado like the one studied here. As previously suggested for birds (Silva 1996), the number of forest-dependent euglossines in the Cerrado probably decreases with increasing distance to their forest source-biome.

Our results might suggest that riparian forests are not necessary for the conservation of Euglossina in the Cerrado. It should be considered, though, that what our data actually show is that the orchid bees present in the Cerrado domain are able to explore both the savanic and the forest environments. Since our data result from attracting bees to scent baits, it is possible for their greater abundance in the open cerrado s.s. to be just a consequence of the aromatic plume more easily dispersing there than in the more closed forest environment, which slow down winds and might restrict the area reached by the attractive compounds (Bonilla-Gómez 1999). Factors such as different air temperatures and wind speed and direction can cause the formation of different odor plumes in different sites (Murlis et al. 1992). It is possible, then, that orchid bees vague through both environments, exploiting whatever resources they can find in each of them. Neves \& Viana (1999), for example, suggested that riparian forests would be important for orchid bees, offering them nesting sites, food resources and protection against intense solar radiation and winds (Moura \& Schlindwein 2009).

The data presented here, collected at a core area of the Cerrado, when compared to the results of previous inventories in marginal areas of this domain (Nemésio \& Faria 2004, Alvarenga et al. 2007) suggest an impoverishment of diversity and abundance towards 
the Cerrado core and the lack of an endemic orchid-bee fauna in this biome; they also suggest a close relationship with the Atlantic Forest fauna (Nemésio \& Faria 2004, Nemésio \& Silveira 2007b). It is suggested that the Cerrado orchid bee fauna is only a subset of the Atlantic Forest euglossine fauna.

It can be concluded, that, in the Fazenda Brejão: i) the species compositions of the euglossine fauna in the cerrado s.s. and in the riparian forests are the same; ii) riparian forests seem not to have special biogeographic role in relation to definition of the composition of the Cerrado euglossine fauna - they apparently do not act as mesic refuges, and do not house a characteristic fauna, and probably are not acting as corridors for the colonization of the Cerrado domain by euglossine species dependent on forest environments.

\section{Acknowledgements}

To V\&M Florestal Ltda and US-Fish \& Wildlife Service for financial support; to CAPES for the scholarship given to the first author; to R.B. Martines for help in fieldwork and logistic support; to Cláudia Simeão, Leandro Matos Santos and Roselaini do Carmo who kindly assisted in data collecting; to the employees of the Fazenda Brejão for their support; André Hirsch for the georeference work that is depicted in Figure 1 (the entire responsibility for any mistake when interpreting André's work - preparing the grayscale map - is ours); Elaine Soares kindly helped with the preparation of Figure 1; we acknowledge the two anonymous referees, whose criticisms and suggestions improved the manuscript.

\section{References}

AGUIAR, W.M. \& GAGLIANONE, M.C. 2008. Comunidade de abelhas Euglossina (Hymenoptera: Apidae) em remanescentes de mata estacional semidecidual sobre tabuleiro no estado do Rio de Janeiro. Neotrop. Entomol. 37(2):118-125. PMid:18506288. http://dx.doi.org/10.1590/ S1519-566X2008000200002

AGUILAR, J.B.V. 1990. Contribuição ao conhecimento dos Euglossini (Hymenoptera: Apidae) do estado da Bahia, Brasil. Dissertação de Mestrado, Universidade de São Paulo, São Paulo.

AIZEN, M.A. \& FEINSINGER, P. 1994. Habitat fragmentation, native insect pollinators, and feral honey bees in Argentine 'Chaco Serrano'. Ecol. Appl. 4(2):378-392. http://dx.doi.org/10.2307/1941941

ALBUQUERQUE, P.M.C. \& MENDONÇA, J.A. 1996. Anthophoridae (Hymenoptera: Apoidea) e flora associada em uma formação de cerrado no município de Barreirinhas, MA. Brasil. Acta Amaz. 26(1-2):45-54.

ALVARENGA, P.E.F., FREITAS, R.F. \& AUGUSTO, S.C. 2007. Diversidade de Euglossini (Hymenoptera: Apidae) em áreas de cerrado do Triângulo Mineiro, MG. Biosci. J. 23(suplemento 1):30-37.

ANDENA, S.R., BEGO, L.R. \& MECHI, M.R. 2005. A comunidade de abelhas (Hymenoptera, Apoidea) de uma área de cerrado (Corumbataí, SP) e suas visitas às flores. Rev. Bras. Zooc. 7(1):55-91.

ANJOS-SILVA, E.J. 2008. Discovery of Euglossa (Euglossa) cognata Moure (Apidae: Euglossini) in the Platina Basin, Mato Grosso state, Brazil. Biot. Neotrop. 8(2):79-83. http://dx.doi.org/10.1590/S167606032008000200008

ANJOS-SILVA, E.J., CAMILLO, E. \& GARÓFALO, C.A. 2006. Occurrence of Aglae caerulea Lepeletier \& Serville (Hymenoptera: Apidae: Euglossini) in the Parque Nacional da Chapada dos Guimarães, Mato Grosso State, Brazil. Neotrop. Entomol. 35(6):868-870. PMid:17273723. http://dx.doi.org/10.1590/S1519-566X2006000600024

BEGON, M., HARPER, J.L. \& TOWNSEND, C.R. 1990. Ecology: individuals, populations and communities. Blackwell Scientific Publications, Oxford.

BONILLA-GÓMEZ, M.A. 1999. Caracterização da Estrutura Espaçotemporal da Comunidade de Abelhas Euglossinas (Hymenoptera, Apidae) na Hiléia Bahiana. Tese de doutoramento, Universidade Estadual de Campinas, Campinas.
BONILLA-GÓMEZ, M.A. \& NATES-PARRA, G. 1992. Abejas euglosinas de Colombia (Hymenoptera: Apidae) I. Claves Ilustradas. Caldasia 17(1):149-172.

BROSI, B.J. 2009. The effects of forest fragmentation on euglossine bee communities (Hymenoptera: Apidae: Euglossini). Biol. Conserv. 142:414423. http://dx.doi.org/10.1016/j.biocon.2008.11.003

CAMARGO, A.J.A. \& BECKER, V.O. 1999. Saturniidae (Lepidoptera) from the Brazilian Cerrado: composition and biogeographic relationships. Biotropica 31(4):696-705. http://dx.doi.org/10.1111/j.1744-7429.1999. tb00420.x

CARRIJO, T.F., BRANDÃO, D., OLIVEIRA, D.E., COSTA, D.A. \& SANTOS, T. 2009. Effects of pasture implantation on the termite (Isoptera) fauna in the Central Brazilian Savanna (Cerrado). J. Insect Conserv. 13(6):575-581. http://dx.doi.org/10.1007/s10841-008-9205-y

CARVALHO, A.M.C. \& BEGO L.R. 1998. Studies on Apoidea fauna of cerrado vegetation at the Panga Ecological Reserve, Uberlândia, MG, Brazil. Rev. Bras. Entomol. 40(2):147-156.

CARVALHO, C.C., RÊGO, M.M.C. \& MENDES, F.N. 2006. Dinâmica de populações de Euglossina (Hymenoptera, Apidae) em mata ciliar; Urbano Santos, Maranhão, Brasil. Iheringia Ser. Zool. 96(2):249-256. http:// dx.doi.org/10.1590/S0073-47212006000200016

CASTRO, A.P., QUIRINO, B.F., PAPPAS JUNIOR, G., KUROKAWA, A.S., LEONARDECZ, E. \& KRÜGER, R.H. 2008. Diversity of soil fungal communities of Cerrado and its closely surrounding agriculture fields. Arch. Microbiol. 190(2):129-139. PMid:18458875. http://dx.doi. org/10.1007/s00203-008-0374-6

DINIZ, I.R. \& KITAYAMA, K. 1998. Seasonality of vespid species (Hymenoptera: Vespidae) in a central Brazilian cerrado. Rev. Biol. Trop. 46(1):109-114.

DODSON, C.H., DRESSLER, R.L., HILLS, H.G., ADAMS, R.M. \& WILLIAMS, N.H. 1969. Biologically active compounds in orchid fragrances. Science 164(3885):1243-1249. PMid:17772561. http://dx.doi. org/10.1126/science.164.3885.1243

DRESSLER, R.L. 1982. Biology of the orchid bees (Euglossini). Annu. Rev. Ecol. Syst. 13:373-394. http://dx.doi.org/10.1146/annurev. es.13.110182.002105

FARIA, L.R.R. \& MELO, G.A.R. 2007. Species of Euglossa (Glossura) in the Brazilian Atlantic forest, with taxonomic notes on Euglossa stellfeldi Moure (Hymenoptera, Apidae, Euglossina). Rev. Bras. Entomol. 51(3):275-284.

FREITAS, R.F. 2009. Diversidade e sazonalidade de abelhas Euglossini Latreille (Hymenoptera: Apidae) em fitofisionomias do bioma Cerrado em Uberlândia, MG. Dissertação de Mestrado, Universidade Federal de Uberlândia, Uberlândia.

GOLFARI, L. 1975. Zoneamento ecológico do estado de Minas Gerais para reflorestamento. Projeto de Desenvolvimento e Pesquisa Florestal Prodepef, Rio de Janeiro.

GOODLAND, R. 1971. A physiognomic analysis of the "Cerrado" vegetation of central Brazil. J. Ecol. 59(2):411-419. http://dx.doi. org/10.2307/2258321

JESUS, B.M.V. 2000. Riqueza e abundância sazonal de Euglossini (Hymenoptera, Apidae) em fragmentos de matas do estado de São Paulo. Tese de Doutorado, Universidade de São Paulo, Ribeirão Preto.

LACHER JUNIOR., T.E. \& ALHO, C.J.R. 1998. Terrestrial small mammal richness and habitat associations in an Amazon forest-Cerrado contact zone. Biotropica 33(1):171-181.

LUDWIG, J.A. \& REYNOLDS, J.F. 1988. Statistical Ecology: a primer on methods and computing. Wiley Interscience, New York.

MAGURRAN, A.E. 1988. Ecological diversity and its measurement. Princeton University Press, Princeton.

MANLY, B.F. 1994. Multivariate statistical methods: a primer. Chapmann \& Hall, Londres.

MARES, M.A. \& ERNEST, K.A. 1995. Population and community ecology of small mammals in a gallery forest of Central Brazil. J. Mammal. 76(3):750-768. http://dx.doi.org/10.2307/1382745 
MENDES, F.N., RÊGO, M.M.C. \& CARVALHO, C.C. 2008. Abelhas Euglossina (Hymenoptera, Apidae) coletadas em uma monocultura de eucalipto circundada por Cerrado em Urbano Santos, Maranhão, Brasil. Iheringia Ser. Zool. 98(3):285-290. http://dx.doi.org/10.1590/S007347212008000300001

MILET-PINHEIRO, P. \& SCHLINDWEIN, C. 2005. Do euglossine males (Apidae, Euglossini) leave tropical rainforest to collect fragrances in sugarcane monocultures? Rev. Bras. Zool. 22(4):853-858. http://dx.doi. org/10.1590/S0101-81752005000400008

MORATO, E.F. 1994. Abundância e riqueza de machos de Euglossini (Hymenoptera: Apidae) em mata de terra firme e áreas de derrubada nas vizinhanças de Manaus (Brasil). Bol. Mus. Para. Emílio Goeldi Ser. Zool. 10(1):95-105.

MOURA, D.C. \& SCHLINDWEIN, C. 2009. Mata ciliar do Rio São Francisco como biocorredor para Euglossini (Hymenoptera: Apidae) de florestas tropicais úmidas. Neotrop. Entomol. 38(2):281-284. PMid:19488520. http://dx.doi.org/10.1590/S1519-566X2009000200018

MOURE, J.S., MELO, G.A.R. \& FARIA, L.R.R. 2007. Euglossini Latreille, 1802. In Catalogue of Bees (Hymenoptera, Apoidea) in the Neotropical Region (J.S. Moure, D. Urban \& G.A.R. Melo, eds.). Sociedade Brasileira de Entomologia, Curitiba, p.214-255.

MURCIA, C. 1995. Edge effect in fragmented forests: implications for conservation. TREE 10(2):58-62. http://dx.doi.org/10.1016/S01695347(00)88977-6

MURLIS, J., ELKINTON, J.S. \& CARDÉ, R.T. 1992. Odor plumes and how insect use them. Ann. Rev. Entomol. 37:505-532. http://dx.doi. org/10.1146/annurev.en.37.010192.002445

MYERS, N., MITTERMEIER, R.A., MITTERMEIER, C.G., FONSECA, G.A.B. \& KENT, J. 2000. Biodiversity hotspots for conservation priorities. Nature 403:853-858. PMid:10706275. http://dx.doi. org/10.1038/35002501

NEMÉSIO, A. 2003. Preliminarly sampling of Euglossina (Hymenoptera: Apidae: Apini) of Reserva Particular do Patrimônio Natural "Feliciano Miguel Abdala", Caratinga, Minas Gerais, southeastern Brazil. Lundiana 4(2):121-124.

NEMÉSIO, A. 2009. Orchid bees (Hymenoptera: Apidae) of the Brazilian Atlantic Forest. Zootaxa 2041:1-242.

NEMÉSIO, A. \& FARIA, L.R.R. 2004. First assessment of the orchid-bee fauna (Hymenoptera: Apidae) at Parque Estadual do Rio Preto, a cerrado area in southeastern Brazil. Lundiana 5(2):113-117.

NEMÉSIO, A. \& SILVEIRA, F.A. 2006a. Edge effects on the orchid-bee fauna (Hymenoptera: Apidae) at a large remnant of Atlantic Rain Forest in southeastern Brazil. Neotrop. Entomol. 35(3):313-323. http://dx.doi. org/10.1590/S1519-566X2006000300004

NEMÉSIO, A. \& SILVEIRA, F.A. 2006b. Deriving ecological relationships from geographical correlations between host and parasitic species: an example with orchid bees. J. Biogeogr. 33(1):91-97. http://dx.doi. org/10.1111/j.1365-2699.2005.01370.x

NEMÉSIO, A. \& SILVEIRA, F.A. 2007a. Orchid bee fauna (Hymenoptera: Apidae: Euglossina) of Atlantic Forest fragments inside an urban area in southeastern Brazil. Neotrop. Entomol. 36(2):186-191. http://dx.doi. org/10.1590/S1519-566X2007000200003

NEMÉSIO, A \& SILVEIRA, F.A. 2007b. Diversity and distribution of orchid bees (Hymenoptera: Apidae) with a revised checklist of species. Neotrop. Entomol. 36(6):874-888. http://dx.doi.org/10.1590/S1519566X2007000600008

NEMÉSIO, A. \& SILVEIRA, F.A. 2010. Forest fragments with larger core areas better sustain diverse orchid bee faunas (Hymenoptera: Apidae: Euglossina). Neotrop. Entomol. 39(4):555-561. http://dx.doi.org/10.1590/ S1519-566X2010000400014

NEMÉSIO, A., AUGUSTO, S.C. \& ALMEIDA, E.A.B. 2007. Euglossa decorata Smith (Hymenoptera: Apidae) in central Brazil - biogeographic implications. Lundiana 8(1):57-61.
NEVES, E.L. \& VIANA, B.F. 1999. Comunidade de machos de Euglossinae (Hymenoptera: Apidae) das matas ciliares da margem esquerda do Médio Rio São Francisco, Bahia. An. Soc. Entomol. Bras. 28(2):201-210. http:// dx.doi.org/10.1590/S0301-80591999000200002

NEVES, E.L. \& VIANA, B.F. 2003. A fauna de abelhas da subtribo Euglossina (Hymenoptera, Apidae) do estado da Bahia, Brasil. In Apoidea Neotropica: Homenagem aos 90 anos de Jesus Santiago Moure (G.A.R Melo \& I. Alves-dos-Santos, eds.). Editora UNESC, Criciúma, p.223-230.

OLIVEIRA, P.E. 1998. Fenologia e biologia reprodutiva das espécies de Cerrado. In Cerrado: Ambiente e flora (S.M. Sano \& S.P. Almeida, eds.). Embrapa-CPAC, Planaltina, p.169-192.

OLIVEIRA, M.L. \& CAMPOS, L.A.O. 1995. Abundância, riqueza e diversidade de abelhas Euglossinae (Hymenoptera, Apidae) em florestas contínuas de terra firme na Amazônica Central, Brasil. Rev. Bras. Zool. 12(3):547-556. http://dx.doi.org/10.1590/S010181751995000300009

OLIVEIRA-FILHO, A.T. \& RATTER, J.A. 1995. A study of the origin of Central Brazilian forests by the analysis of plant species distribution patterns. Edinb. J. Bot. 52(2):141-194. http://dx.doi.org/10.1017/ S0960428600000949

PINHEIRO-MACHADO, C., ALVES-DOS-SANTOS, I., IMPERATRIZFONSECA, V.L., KLEINERT, A.M.P. \& SILVEIRA, F.A. 2002. Brazilian bee surveys: state of knowledge, conservation and sustainable use. In: Pollinating Bees - The Conservation link between agriculture and nature (Kevan, P. \& Imperatriz-Fonseca, V.L., eds.). Ministério do Meio Ambiente, Brasília, p.115-129.

PINHEIRO, C.E.G. \& ORTIZ, J.V.C. 1992. Communities of fruitfeeding butterflies along a vegetation gradient in central Brazil. J. Biogeog. 19(5):505-511. http://dx.doi.org/10.2307/2845769

PERUQUETTI, R.C., CAMPOS, L.A.O., COELHO, C.D.P., ABRANTES, C.V.M. \& LISBOA, L.C. 1999. Abelhas Euglossini (Apidae) de áreas de Mata Atlântica: abundância, riqueza e aspectos biológicos. Rev. Bras. Zool. 16(2):101-118. http://dx.doi.org/10.1590/S010181751999000600012

QUEIROZ-NETO, J.P. 1982. Solos da região dos cerrados e suas interpretações (revisão de literatura). Rev. Bras. Ciênc. Solo 6(1):1-12.

RAW, A. 1989. The dispersal of euglossine bees between isolated patches of eastern Brazilian wet Forest. Rev. Bras. Entomol. 33(1):103-107.

RATTER, J.A., RIBEIRO, J.F. \& BRIDGEWATER, S. 1997. The Brazilian cerrado vegetation and threats to its biodiversity. Ann. Bot. 80(3):223-230 http://dx.doi.org/10.1006/anbo.1997.0469

REBÊLO, J.M.M. \& MOURE, J.S. 1996. As espécies de Euglossa Latreille do nordeste do estado de São Paulo (Apidae, Euglossinae). Rev. Bras. Zool. 12(3):445-466.

REBÊLO, J.M.M. \& CABRAL, A.J.M. 1997. Abelhas Euglossinae de Barreirinhas, zona do litoral da baixada oriental maranhense. Acta Amaz. 27(2):145-152.

REBÊLO, J.M.M. \& GARÓFALO, C.A. 1997. Comunidades de machos de Euglossinae (Hymenoptera, Apidae) em matas semidecíduas do nordeste do estado de São Paulo. An. Soc. Entomol. Bras. 26(2):243-255.

REDFORD, K.H. \& FONSECA, G.A.B. 1986. The role of gallery forests in the zoogeography of the cerrado's non-volant mammalian fauna. Biotropica 18(2):126-135. http://dx.doi.org/10.2307/2388755

RIBEIRO, J.F. \& WALTER, B.M.T. 1998. Fitofisionomias do bioma Cerrado. In Cerrado: ambiente e flora (S.M. Sano \& S.P. Almeida, eds.). EmbrapaCpac, Planaltina, p.89-168.

RICKETTS, T.H., REGETZ, J., STEFFAN-DEWENTER, I., CUNNINGHAM, S.A., KREMEN, C., BOGDANSKI, A., GEMMILL-HERREN, B., GREENLEAF, S.S., KLEIN, A.M., MAYFIELD, M.M., MORANDIN, L.A., OCHIENG, A. \& VIANA, B.F. 2008. Landscape effects on crop pollination services: are there general patterns? Ecol. Lett. 11(5):499-515. PMid:18294214. http://dx.doi.org/10.1111/j.1461-0248.2008.01157.x

RIZZINI, C.T. 1997. Tratado de fitogeografia do Brasil. Editora Âmbito Cultural, Rio de Janeiro. 
ROUBIK, D.W. \& HANSON, P.E. 2004. Orchid bees of tropical America: biology and field guide. INBio, Santo Domingo de Heredia.

SCOLFORO, J.R.S., MELLO, J.M., ACERBI JUNIOR, F.W., OLIVEIRA, A.D., BORGES, L.F.R. \& OLIVEIRA, L.T. 2001. Diagnóstico e proposta de manejo de fragmentos florestais nativos na Vallourec \& Mannesmann Florestal, região de Brasilândia, Minas Gerais. Universidade Federal de Lavras, Lavras.

SILVA, J.M.C. 1996. Distribution of Amazonian and Atlantic birds in gallery forests of the Cerrado region, South America. Ornitol. Neotrop. 7(1):1-18.

SILVA, J.M.C. 1997. Endemic bird species and conservation in the Cerrado region, South America. Biodivers. Conserv. 6(3):435-450. http://dx.doi. org/10.1023/A:1018368809116

SILVA, F.S. \& REBÊLO, J.M.M. 1999. Distribuição das abelhas Euglossini (Hymenoptera: Apidae) no estado do Maranhão, Brasil. An. Soc. Entomol. Bras. 28(3):389-401.

SILVA, F.S. \& REBÊLO, J.M.M. 2002. Population dynamics of Euglossinae bees (Hymenoptera, Apidae) in an early second-growth forest of Cajual Island, in the state of Maranhão, Brazil. Braz. J. Biol. 62(1):15-23.

SILVA, H.G., FIGUEIREDO, N. \& ANDRADE, G.V. 2008. Estrutura da vegetação de um cerradão e a heterogeneidade regional do Cerrado no Maranhão, Brasil. Rev. Árvore 32(5):921-930. http://dx.doi.org/10.1590/ S0100-67622008000500017

SILVEIRA, F.A. \& CAMPOS, M.J.O. 1995. A melissofauna de Corumbataí (SP) e Paraopeba (MG) e uma análise da biogeografia das abelhas do cerrado brasileiro (Hymenoptera, Apoidea). Rev. Bras. Entomol. 39(2):371-401.
SNEATH, P.H.A. \& SOKAL, R.R. 1973. Numerical taxonomy. The principles and practice of numerical classification. W.H. Freeman, San Francisco.

SOFIA, S.H. \& SUZUKI, K.M. 2004. Comunidades de abelhas Euglossina (Hymenoptera: Apidae) em fragmentos florestais no sul do Brasil. Neotrop. Entomol. 33(6):693-702. http://dx.doi.org/10.1590/S1519566X2004000600006

STEFFAN-DEWENTER, I., MÜNZENBERG, U., BÜRGER, C., THIES, C. \& TSCHARNTKE, T. 2002. Scale dependent effects of landscape context on three pollinator guilds. Ecology 83(5):1421-1432. http://dx.doi. org/10.1890/0012-9658(2002)083[1421:SDEOLC]2.0.CO;2

STORCK-TONON, D., MORATO, E.F. \& OLIVEIRA, M.L. 2009. Fauna de Euglossina (Hymenoptera: Apidae) da Amazônia Sul-Ocidental, Acre, Brasil. Acta Amaz. 39(3):693-706. http://dx.doi.org/10.1590/S004459672009000300026

TONHASCA JUNIOR, A., BLACKMER, J.L. \& ALBUQUERQUE, G.S. 2002. Abundance and diversity of euglossine bees in the fragmented landscape of the Brazilian Atlantic Forest. Biotropica 34(3):416-422.

TONHASCA JUNIOR, A., ALBUQUERQUE, G.S. \& BLACKMER, J.L. 2003. Dispersal of euglossine bees between fragments of the brazilian Atlantic Forest. J. Trop. Ecol. 19(1):99-102.

WOLDA, H. 1981. Similarity indices, sample sizes and diversity. Oecologia 50(3):296-302. http://dx.doi.org/10.1007/BF00344966

ZAR, J.H. 1996. Biostatistical analysis. Prentice Hall, New Jersey. 